\title{
IDENTITAS KRISTEN DALAM REALITAS HIDUP BERBELASKASIHAN: MEMAKNAI KISAH ORANG SAMARIA YANG MURAH HATI
}

\author{
I Made Suardana ${ }^{1)^{*}}$ \\ ${ }^{1)}$ Dosen Pascasarjana Sekolah Tinggi Agama Kristen Negeri (STAKN) Toraja \\ ${ }^{*}$ Penulis korespondensi: suardanamade_stakntoraja@yahoo.com
}

\begin{abstract}
Abstrak
Pesan teks Lukas 10:25-37 sangat jelas yaitu kehidupan Kristen, bukanlah soal penampilan fisik (sebuah kehidupan yang membangun religiositas tanpa kekuatan spiritualitas). Identitas kehidupan Kristen didirikan pada dataran berbelaskasihan, maka sikap belas kasihan dalam ketulusan dan kerelaan adalah tiang kokohnya. Terciptanya kehidupan berbagi yang semakin menyentuh kedalaman kehidupan spiritualitas yang memulihkan, menghidupkan dan menyelamatkan adalah identitas hidup Kristen. Kekristenan menghadapi berbagai tantangan tidak hanya bergerak pada tataran konsep, tetapi memproklamasikan sikap yang membangun perubahan hidup. Hal itu menegaskan bahwa kematangan konsep tentang kehidupan dengan sendirinya bermakna memberdayakan kehidupan senada dengan kematangan konsep tersebut. Belas kasihan orang Samaria yang tampak adalah akibat kepenuhan belas kasihan di dalam hatinya, atau melimpah ruah di dalam hatinya. Sangat paradoks apabila menegaskan diri rohani, tetapi sikap hidup jauh dari tabiat atau karakter hidup rohani tersebut.
\end{abstract}

Kata-kata kunci: identitas, berbelaskasihan, hidup kristen, orang Samaria, murah hati

The message of Luke 10: 25-37 is very clear that the Christian life is not about appearances (a life that develops religiosity without spirituality). The identity of the Christian life is founded on the basis of mercy, thus the attitude of compassion accompanied by sincerity and willingness is one of its established pillars. This creation of a shared life which increasingly touches the depths of a spiritual life which restores, revives, and saves is the identity of a Christian life. Christianity faces various challenges that not only operate at the level of concepts, but also at the level of proclaimed attitudes which create life changes. This emphasizes that the maturity of this concept about the Christian life itself means an empowering life that is in line with the maturity of this concept. The mercy of the Samaritan which is visible in this text is due to the fullness of mercy in his heart, or the mercy that flows out from his heart. It is very oxymoronic if someone emphasizes that they are spiritual, but their attitudes are far from the nature and character of the spiritual life they claim to have. 
Keywords: identity, compassion, christian life, Samaritan, mercy

\section{Pendahuluan}

Lukas mengawali dengan mencatat perumpamaan orang Samaria yang murah hati, yakni tentang tanya jawab antara seorang ahli Taurat ${ }^{1}$ dengan Yesus sehubungan dengan kehidupan kekal. Boland memahami bahwa, Lukas menampilkan tokoh ahli Taurat tersebut datang untuk mencobai Yesus, yang mempertanyakan kepada Yesus tentang "Perintah Utama." E. Earle Ellis mencatat bahwa struktur dari teks Lukas 10:2037 tersebut terbagi ke dalam dua tingkatan cerita, pertama, menyangkut strikes an optimistic note (25-28), ${ }^{3}$ Stefan Leks memberi judul pada bagian pertama tersebut sebagai "kasih menghasilkan hidup yang kekal". 4 Sedangkan pada bagian kedua adalah, the core of the passage, reveals why "the great commandment" did not enable one to "inherit eternal life.".

Dalam hal ini Stefan Leks menyimpulkan bahwa:

Perumpamaan ini diucapkan Yesus dalam rangka sebuah dialog, sehingga jangan dibaca sebagai ilustrasi atau contoh yang tinggal ditiru saja. Seluruh isinya tersusun demikian rupa, sehingga ahli hukum terpaksa mengidentifikasikan dirinya dengan orang yang dirampok itu. Dialah yang seolah-olah terbaring di pinggir jalan sambil memerhatikan para pejalan kaki. Orang lewat menjauh, tetapi seorang mendekat. Ahli Taurat mengetahui dengan pasti siapa sesamanya seandainya dialah yang dirampok dan berlumur darah sambil mengharapkan pertolongan. Maka, kiranya ia mengerti pula, mengapa Yesus berkata kepadanya, "Pergilah, perbuatlah demikian!" Ia kiranya mengerti pesan Yesus yang dapat dirumuskan begini: Daripada sibuk memperdebatkan definisi "sesama,"

${ }^{1}$ Berdasarkan Bible Works 7 untuk kata ahli Taurat dipakai kata nomikos yang berarti pertaining to the law, one learned in the law. In the NT an interpreter and teacher of the Mosaic law. Leks mencatat bahwa pengunaan kata Yunani nomikos tersebut menegaskan seorang ahli hukum, o nomikos (legal expert, jurist, lawyer, lihat Mat. 22:35; Luk. 7:30; 10:25; 11:45f, 52, 53;14:3; Tit. 3:13). Stefan Leks, Tafsir Injil Lukas (Yogyakarta: Kanisius, 2003), 295. Boland dan Naipospos mencatat bahwa, Lukas menerjemahkan secara harfiah "ahli Taurat" menjadi "guru hukum." Kata itu khusus dipakai oleh Lukas untuk menegaskan bahwa mereka terutama mempelajari kitab-kitab Taurat untuk memikirkan seluk beluk undang-undang dan peraturan-peraturan keagamaan. Yesus mengecam kehidupan para ahli-ahli kerohanian di kalangan Yahudi. B. J. Boland, dan P.S. Naipospos, Tafsiran Alkitab Injil Lukas (Jakarta: BPK Gunung Mulia, 1996), 128, 305.

${ }^{2}$ Boland dan Naipospos, 267.

${ }^{3}$ E. Earle Ellis, The Gospel of Luke, The New Century Bible Commentary (Grand Rapids: Wm. B. Eerdmans Publishing Company, 1987), 159.

${ }^{4}$ Stefan Leks, Tafsir Injil Lukas (Yogyakarta: Kanisius, 2003), 294.

${ }^{5}$ Ellis, 159. 
jadilah sesama bagi orang lain. ${ }^{6}$

Sebagaimana yang disimpulkan Leks, dua pembagian tersebut adalah keutuhan identitas Kristen. Menjadi Kristen adalah menjadi sesama bagi orang lain. Menjadi sesama adalah realitas berbelaskasihan. Kekuatan hidup berbelaskasihan adalah kasih, kasihlah yang menempatkan hidup berbelaskasihan tersebut adalah perjumpaan hidup pada kekekalan.

\section{Konsep Hidup Berbelaskasihan: Memaknai Kisah Orang Samaria yang Murah Hati}

Sehubungan dengan pengajaran dari teks ini, Yesus membangun pengajaran-Nya dengan mengangkat suatu perumpamaan tentang seorang Samaria yang murah hati. Boland dan Naipospos mencatat bahwa, pertanyaan yang menjadi percakapan antara ahli Taurat dengan Yesus adalah seputar "hidup kekal." Boland dan Naipospos menegaskan bahwa, jika dikenakan kepada keseharian hidup Kristen sekarang, hidup kekal tersebut bukanlah menyangkut kuantitas hidup (jadi dengan lamanya) tetapi justru menyangkut kualitas. Boland dan Naipospos menjelaskan bahwa, hal mengenai hidup yang kekal bukanlah persoalan hidup tanpa akhirnya, tetapi suatu hidup yang mutunya lebih tinggi, yakni hidup yang tulen dan sejati seperti yang diperoleh dengan cara hidup dalam persekutuan dengan Allah. ${ }^{7}$ Gerald W. Schlabach mencatat bahwa "Of the Samaritan, Jesus says simply that he had compassion. The lawyer recognizes that he showed mercy. This is a clue. Throughout the Gospel, Jesus consistently links God's Mercy toward us with the mercy we show others." Sehubungan dengan itu, kesejajaran perumpamaan orang Samaria yang murah hati, dapat digambarkan melalui pengampunan dan kasih Yesus yang besar kepada seorang perempuan berdosa, ${ }^{9}$ Yesus berkata

\footnotetext{
${ }^{6}$ Leks, 294.

${ }^{7}$ Boland dan Naipospos, 268.

${ }^{8}$ Gerald W. Schlabach, And Who is My Neighbor? Poverty, Privilege, and the Gospel of
} Christ (Waterloo: Herald Press, 1990), 115. Bandingkan dengan Mat. 5:7; Luk. 6:36; "Blessed are the merciful, for they will be shown mercy," Mat. 6:12; Luk. 11:4, "In the Lord's prayer we pray, "forgive us our debts, as we also have forgiven our debtors."

${ }_{9}^{9}$ Perempuan berdosa ini ditegaskan sebagai seorang wanita tunasusila (Luk. 7:37), "Di kota itu ada seorang perempuan yang terkenal sebagai seorang berdosa. Ketika perempuan itu mendengar, bahwa Yesus sedang makan di rumah orang Farisi itu, datanglah ia membawa sebuah buli-buli pualam berisi minyak wangi. ...lalu membasahi kaki-Nya itu dengan air matanya dan menyekanya dengan rambutnya, kemudian ia mencium kaki-Nya dan meminyakinya dengan minyak wangi itu. Yesus berkata kepadanya, "Dosamu sudah diampuni, ...imanmu telah menyelamatkan engkau, pergilah dengan selamat!" (Luk. 7:49-50). 
kepadanya, "Dosanya yang banyak itu telah diampuni, sebab ia telah banyak berbuat kasih. Tetapi orang yang sedikit diampuni, sedikit juga ia berbuat kasih." Lalu Ia berkata kepada perempuan itu: "Dosamu telah diampuni" (Luk. 7:36-50). Secara prinsip kasih, perumpamaan orang Samaria yang murah hati berdiri pada posisi pemberi kasih yang tinggi, yang tidak melihat pada nilai timbal balik (quid pro quo). Kasih yang memulihkan dan menghidupkan.

Menurut Gerald W. Schlabach,

To love much, to freely show mercy, to instinctively sense compassion, to serve others, to turn toward those who are poor for this we desperately need to remember just how much mercy God has shown us. Throughout the entire Bible, this is the pattern, "we love because [God] first love us" (1 John 4:19). ${ }^{10}$

Sehubungan dengan tujuan penulis mengangkat perumpamaan orang Samaria yang murah hati menghubungkannya dengan identitas hidup Kristen dalam realitas berbelaskasihan, maka kata-kata kunci yang terkait secara langsung dapat dijabarkan maknanya sebagai berikut:

1. Konsep mengasihi sesama manusia menjadi topik penting mewakili nilai hidup kekal. Pertanyaan ahli Taurat sehubungan dengan "hidup kekal" dimaknai Yesus dengan kesiapan tidak hanya mengetahui (seperti ahli Taurat ketahui) tetapi melakukannya dengan tuntas. Yesus berkata, "perbuatlah demikian, maka kamu akan hidup" (Luk. 10:28). Frasa Yunani untuk menjelaskan kalimat tersebut adalah eipen de autô orthôs apekrithês touto poiei kai zêsê (Luk. 10:28). Kata poiei ${ }^{11}$ mengedepankan makna berupa tindakan aktif, tindakan sebagai respons terhadap sesuatu. KJV menerjemahkan to do, dalam hal ini dimaknai do perform, yakni tanggung jawab untuk benar-benar melakukanya. Ahli Taurat tersebut sudah mengetahui kedua hukum standar kehidupan keimaman orang Yahudi, tetapi hanya sebatas tahu, tanpa bermakna perbuatan. Maka Yesus menegaskan, "apa yang engkau telah ketahui dengan benar (orthôs), perbuatlah demikian, atau lakukanlah seperti kebenaran yang engkau ketahui, maka engkau akan hidup (zao). Leks menekankan dalam tulisannya memaknai nilai hidup tersebut dalam pemahaman "jika kasih terwujud dalam hidupnya, maka ia akan mewarisi kehidupan kekal. ${ }^{12}$

${ }^{10}$ Gerald W. Schlabach, And Who is My Neighbor? Poverty, Privilege, and the Gospel of Christ. Waterloo: Herald Press, 1990), 115.

${ }^{11}$ Bible Works 7, s.v. poiei, adalah verb imperative present active 2nd person singular yang artinya commit, cause, work, show, fulfil, deal, perform.

${ }^{12}$ Leks, 298. 
2. Yesus menggambarkan keadaan seorang Samaria yang memiliki hati yang tulus dan rela berkorban. Hati adalah pusat kehidupan. "Jagalah hatimu dengan segala kewaspadaan, karena dari situlah terpancar kehidupan" (Amsal 44:23). Istilah yang sama juga dikenakan pada orang Samaria yang memiliki hati yang tergerak oleh belas kasihan. Tergerak oleh belas kasihan sama halnya hati yang memancarkan kehidupan. Hati yang tergerak oleh belas kasihan dalam teks Yunani dipakai kata esplagkhnisthê (verb indicative aorist passive $3 r d$ person singular) dari kata splagchnizomai. Leks memaknai bahwa kata tersebut berkonotasi dengan terjungkilbaliknya usus-usus dan dengan gelora perasaan iba yang sangat mendalam. ${ }^{13}$ Hal tersebut terbukti dari kontrasnya sikap yang ditunjukkan kedua orang Yahudi tersebut yaitu seorang Lewi dan seorang Imam dibandingkan dengan orang Samaria yang tidak disebutkan siapa dia. ${ }^{14}$ Kontradiksi sikap yang ditunjukan kedua orang Yahudi tersebut adalah sebuah paradoks dari kenyataan hidup sebagai imam dan Lewi yang hidup dengan pengetahuan tentang kebenaran tersebut. Tetapi dalam kenyataannya mengambil sikap menghindari tanggung jawab mengerjakan pengetahuan kebenaran tersebut. Orang Samaria tersebut, mengambil sikap mendekat, merawat, dan segala tanggung jawab yang menyertai pilihannya untuk menolong orang yang terampok tersebut. Lukas mencatatkan orang Samaria tersebut, membersihkan lukanya dengan minyak dan anggur, memberikan jaminan perawatan sampai sembuh. Orang Samaria melakukannya dengan tuntas.

\section{Kerajaan Allah di Bumi: Menakar Identitas Kristen dalam Realitas Berbelaskasihan}

Berbelaskasihan adalah penegasan hidup Yesus kepada mereka yang membutuhkan pertolongan-Nya. Dalam pelayanan-Nya, Yesus memakai sebuah pendekatan melalui perumpamaan. Perumpamaan orang Samaria yang murah hati menegaskan pengajaran Yesus tentang sikap yang harus dibangun oleh orang Kristen terhadap sesama. Dengan gambaran kasih yang besar Yesus menempatkan orang Samaria sebagai pemberi kasih yang besar bagi orang Yahudi yang sama dibenci juga oleh bangsa-Nya. Dengan membangun konsep berbelaskasihan, Yesus menanggapi realitas kehidupan yang ditandai dengan berbagai pergumulan sosial dari orang-

\footnotetext{
${ }^{13}$ Leks, 302.

${ }^{14}$ Samaritan: A person from the district of Samaria located between Judea and Galilee. The Samaritans were despised by the Jews and the two groups had nothing to do with each other. C. I. Scofield, The Scofield Study Bible, New King James Version (Oxford, New York: Oxford University Press, 2002 ), 1418.
} 
orang yang terpinggirkan, kaum miskin, kaum menderita, kaum perempuan dan anak-anak, bahkan kepada kaum atau bangsa yang dianggap kafir oleh orang Yahudi.

Memahami perjumpaan kekristenan dengan pergumulan sosial, Brownlee menegaskan bahwa, "Segala kehidupan orang percaya adalah wujud dari tanggung jawab menyesuaikannya dengan Kerajaan Allah tersebut." 15 Karena itu dalam menjalani hidup sebagai orang Kristen penting menghadirkan dimensi Kerajaan Allah tersebut dalam kenyataan yang memulihkan, menyembuhkan dan memberdayakan. Lukas menghadirkan Yesus sebagai kenyataan kehadiran Kerajaan Allah yang membebaskan dan memulihkan. Marshal menegaskan bahwa konsep Kerajaan Allah senantiasa menjadi ungkapan Yesus dalam mengerjakan pelayanan-Nya sebagai Mesias. ${ }^{16}$ Dalam Lukas 11:20, "Tetapi jika Aku mengusir setan dengan kuasa Allah, maka sesungguhnya Kerajaan Allah sudah datang kepadamu." Helmut Merkel mengatakan bahwa, "Here again it becomes clear that the proclamation of Jesus cannot be separated from His person."17

Bagi orang-orang Yahudi, istilah Kerajaan Allah dimaknai dalam pengertian "pembebasan Yerusalem," atau merujuk pada kehadiran Mesias sebagai pembebas orang-orang Yahudi. ${ }^{18}$ Lukas mencatat bahwa Yesus menjawab pertanyaan tentang pemulihan Israel, "Maka bertanyalah mereka yang berkumpul di situ: "Tuhan, maukah Engkau pada masa ini memulihkan kerajaan bagi Israel?" Jawab-Nya: "Engkau tidak perlu mengetahui masa dan waktu, yang ditetapkan Bapa sendiri menurut kuasa-Nya. Tetapi kamu akan menerima kuasa, kalau Roh Kudus turun ke atas kamu, dan kamu akan menjadi saksi-Ku di Yerusalem dan di seluruh Yudea dan Samaria dan sampai ke ujung bumi (Kis. 1:6-8).

${ }^{15}$ Malcolm Brownlee, Tugas Manusia dalam Dunia Milik Tuhan, Dasar Theologis BagiPekerjaan Orang Kristen dalam Masyarakat (Jakarta: BPK Gunung Mulia, 1997), 58.

16 Marshal, memahami bahwa, para penulis Injil sama-sama menempatkan pengajaran dan pemberitaan Yesus secara khusus terpusat pada kesatuan-Nya dengan Kerajaan Allah. Marshal, Luke: Historian and Theologian, 128.

${ }^{17}$ Helmut Merkel, "The opposition between Jesus and Judaism" in Jesus and The Politics of His Day, eds., Ernst Bammel, C. F. D. Moule (Cambridge, London: Cambridge University Press, 1984), 143.

${ }^{143}$ Ibid., 143.

${ }^{18}$ Groome mencatat bahwa, bagi bangsa Israel, Kerajaan Allah bukan wilayah pemerintahan, juga bukan konsep yang abstrak. Kerajaan Allah adalah simbol yang menunjuk pada kegiatan Allah yang nyata di dalam sejarah yang memperlihatkan kedaulatan Allah. Oleh karena itu Kerajaan Allah telah direalisasikan dan direalisasikan dengan sempurna. Thomas A. Groome, Christian Religious Education; Pendidikan Agama Kristen, Berbagi Cerita dan Visi Kita (Jakarta: BPK Gunung Mulia, 2010), 50-51. 
Dengan demikian, pernyataan Robinson bahwa makna Kerajaan Allah adalah Yesus yang menyatakan kehadiran Kerajaan Allah dalam kuasa mukjizat-Nya. ${ }^{19}$ Johnson mengatakan pendapatnya,

We find Jesus himself proclaimed as $\beta \alpha \sigma i \lambda \varepsilon v$ s (19:38), accused of claiming to be Messiah-King (23:2ff), castigated as such on the cross $(23: 37,38)$, begged there for a place

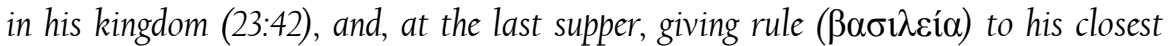
followers (22:29). "The kingdom has been connected to Jesus's work, and has been increasingly pictured as present. But Jesus himself has never yetbeen called a king. Only, just before the Zaccheus incident, he istwice called "Son of David" by the blind man of Jericho, which is apreparation. ${ }^{20}$

Sehubungan dengan Yesus yang menyatakan Kerajaan Allah dalam kuasa mukjizat-Nya, Groome menegaskan bahwa sebagai pemberitaan Kerajaan Allah, Yesus telah malampaui ke-Yahudian-Nya, Yesus menganggap Kerajaan Allah telah datang secara definitif dan menunjukan diri-Nya, karya dan pelayanan-Nya sebagai agen-Nya yang efektif. Dalam diri-Nya Allah aktif menyebabkan kedatangan Kerajaan secara definitif. ${ }^{21}$

Seperti telah ditegaskan sebelumnya bahwa Lukas menonjolkan Yesus dalam totalitas pengajaran-Nya berpusat pada The Kingdom of God, ${ }^{22}$ bahkan Yesus menunjuk diri-Nya adalah kepenuhan hak-hak dari Kerajaan Allah, ${ }^{23}$ yang hadir di tengah-tengah umat-Nya (Luk. 13:28; 11:2; 22:16; 22:29). Dalam Lukas 22:29, dicatat pula "Dan Aku menentukan hak-hak Kerajaan bagi kamu, sama seperti Bapa-Ku menentukannya bagi-Ku." KJV mencatatnya, "And I appoint unto you a kingdom, as my Father

${ }^{19}$ Jesus' favorite term for talking about God acting in our own world, whether God's action is what we would call a "miracle" or not, is this idiom, "kingdom of God" (or "kingdom of heaven"). James M. Robinson, The Gospel Jesus, A Historical Search for the Original Good News (New York: Hmper Collms Publishers, 2005), 164.

${ }^{20}$ Johnson, 83.

${ }^{21}$ Groome, 56.

${ }^{22}$ Bandingkan dengan pernyataan yang dicatatkan Walter Kasper bahwa "The centre and framework of Jesus' preaching and mission was the approaching Kingdom of God. Walter Kasper, Jesus the Christ (New York: T\&T Clark International, 2011), 60. Lihat Lukas $4: 21 ; 4: 43 ; 8: 1 ; 9: 1-6 ; 9: 57-62 ; 17: 20-21$.

${ }^{23}$ Kerajaan Allah dipahami sebagai Kerajaan Surga. Lihat: Wijngaards, 156. Dicatatkan bahwa Kerajaan Allah dengan arti yang jelas dengan Kerajaan surga. Untuk menghindari menyebut Allah, orang-orang Yahudi mengantinya dengan sebutan surga. Lukas menggunakan Kerajaan Allah “... Kerajaan Allah sudah datang kepadamu” (Luk. 11:20); “... Kerajaan Allah ada di antara kamu” (Luk. 17:20-21). G. Dalman, dalam bukunya, The Words of Jesus, Considered in the Light of Post-biblical Jewish Writings and the Aramaic Language (1898. Trans. D. M. Kay. Edinburgh: T\&T Clark, 1902), 93-94., Maurice Casey, 213. 
hath appointed unto me. ${ }^{24}$ Menurut Karl Barth, sebagaimana dikutip A. M. Hunter, penentuan hak-hak Kerajaan Allah tersebut menegaskan bahwa, "in the Gospel the kingdom of God is Christ himself" (In evangelio est Regnum Dei Christusipse). ${ }^{25}$ Hunter juga menjelaskan bahwa,

The kingdom of God is centered in Christ. "if I by the finger of God cast out devils", said Jesus, "then is the kingdom of God come upon you" (Luke 11:20). Here speaks one who incarnates the kingdom. Elsewhere to follow Jesus in to be in the kingdom. Where he is, the kingdom is. Somehow in the gospel the kingdom is Christ himself. ${ }^{26}$

Penegasan tentang Kerajaan Allah adalah Yesus sendiri, penting dimengerti sebagaimana dicatatkan Hunter, bahwa hal itu menyangkut Kerajaan Allah telah dimulai di dalam pelayanan-Nya. ${ }^{27}$ "He Lives, and works, and dies, in the thought of the kingdom of God". ${ }^{28}$ Bob Utley, menegaskan maknanya sebagai "the focal message of Jesus' ministry" ${ }^{29}$ atau, "the Kingdom of God is a central concept of Jesus' preaching (Luk. 4:21; 4:43). ${ }^{30}$ Dengan demikian, pelayanan Yesus ${ }^{31}$ di tengah-tengah dunia adalah linierisasi dari Kerajaan Allah yang hadir, memulihkan, menyembuhkan dan menyelamatkan setiap orang di dalam Yesus. Lukas merangkai tulisannya sebagai Injil yang menghadirkan perhatian Yesus pada pemberitaan Kerajaan Allah. Kerajaan Allah adalah tema pelayanan Yesus memulai pelayanan-Nya di Galilea.Hans Küng mencatat bahwa, "Yesus yang hadir di bumi dan yang telah masuk ke dalam kemulian Allah dan telah diteguhkan Allah, pribadi dan perkara-Nya benar-benar saling terkait." ${ }^{32}$ Yesus telah menggenapkan dalam diri-Nya anugerah Allah yang penuh kasih, pengampunan dan pembebasan tersebut.

Yesus menghadirkan misi pelayanan-Nya dalam kepenuhan belas kasihan yang membebaskan dan memulihkan. Mengusung prinsip berbelaskasihan dalam realita hidup Kristen, Yewangoe memahami

${ }^{24}$ Bible Works 7, s.v. "And I appoint unto you a kingdom, as my Father hath appointed unto me."

${ }^{25}$ A. M. Hunter, Christ And The Kingdom: What Scripture Says About Living In The Kingdom Of God (Michigan: Servant Books, 1980), 93.

${ }^{26}$ Ibid. 8 .

27 Archibald M. Hunter, The Work And Words Of Jesus (Philadelphia: The Westminster Press, 1973), 96.

${ }^{28}$ Ibid., 90.

${ }^{29}$ Utley, 140.

${ }^{30}$ Ibid., 96.

${ }^{31}$ Pernyataan ini juga tersirat dalam Lukas 11:20, 13:18-21; 17:21.

${ }^{32}$ Hans Küng, "Kekhasan Etika Kristen" Dalam Verne H. Fletcher, Lihatlah Sang Manusia, Suatu Pendekatan Pada Etika Kristen Dasar (Jakarta: BPK Gunung Mulia, 2007), 508. 
bahwa, compassion tidak pernah mendahului confession. ${ }^{33}$ Ketegasan ini harus dibangun sebagaimana Yesus menempatkan "kesempurnaan kasihNya" didasarkan pada ketulusan dan ketaatan-Nya kepada Allah saja. Kesempurnaan kasih terhadap sesama tidak akan jelas, jika dipisahkan dari kasih yang utama kepada Allah." ${ }^{34}$ Dalam hal inilah Yewangoe menempatkan bahwa,

Compassion bukan alternatif bagi confession, tetapi merupakan wujud sejati darinya. Sebuah confession yang yang sungguh-sungguh dihayati akan bermuara pada compassion. Sebaliknya, compassion yang tidak sekadar belaskasih manusiawi akan diperteguh justru oleh confession. Dalam compassion kita mengakui bahwa Allah sungguh-sungguh berpihak kepada yang lemah, dengan masuk ke dalam daging (carnis/sarks) dalam peristiwa inkarnasi. Tanpa mengakui peristiwa ini, sulitlah menerapkan compassion tanpa tanpa pamrih. ${ }^{35}$

Karena itu, hal mendasar yang menjadi tanggung jawab kekristenan adalah memaknai nilai belas kasihan tersebut adalah pemberian dari Allah, ${ }^{36}$ karena itu tidak bisa dikerjakan tanpa Allah ada dalam kehidupan ini. Istilah Kerajaan Allah di bumi sebagaimana telah dipaparkan sebelumnya menegaskan makna kehadiran Yesus dalam pelayanan dan kuasa mukjizat-Nya. Perhatian Yesus terhadap kemiskinan, kemelaratan, kesengsaraan, penderitaan, adalah takaran yang terus-menerus harus dikembangkan dan dikenakan orang Kristen terhadap jati diri sebagai pengikut Kristus. Dalam menakar identitas Kristen, prinsip dasar yang harus dipenuhkan adalah hidup berbelaskasihan yakni: Pertama, belas kasihan bersifat proaktif dan tulus; Kedua, berbelaskasihan adalah kesiapan menolong sesama tanpa batas.

Yesus menerapkan prinsip belas kasihan yang bersifat utuh dan proaktif. Hal ini menegaskan wujud perilaku hidup berbelaskasihan tersebut pada kesiapan untuk tidak apatis atau tidak masa bodoh, tetapi bersikap cerdas, terbuka dan membangun kebaikan bersama secara utuh untuk menghasilkan yang terbaik. Joas Adiprasetya mencatat bahwa, pernyataan tentang kehidupan dunia yang secara religius berwarna plural, bukanlah menu yang baru. Ia menegaskan bahwa, hal yang baru justru munculnya kesadaran perlu dirumuskannya sikap teologis yang

${ }^{33}$ A. A. Yewangoe, "Kata Pengantar" dalam Josef P. Widyatmadja, Yesus dan Wong Cilik, xv.

${ }^{34}$ Fletcher, 427.

${ }^{35}$ Yewangoe, "Kata Pengantar", xv.

36 Albert Nolan, Yesus Sebelum Agama Kristen, Warta Gembira yang Memerdekakan (Yogyakarta: Kanisius, 1991), 178. 
memadai dalam menjawab realitas kepelbagaian itu. Istilah yang Joas angkat adalah kesiapan untuk tidak bersikap taken for granted ${ }^{37}$ terhadap kenyataan majemuk yang ada di depan mata, bersikap jujur dan terbuka terhadap kemajemukan dan melihatnya dalam keutuhan diri dan orang lain sebagai orang yang beriman. ${ }^{38}$

Mengangkat konsep taken for granted-nya Joas Adiprasetya, tidak serta merta berarti sebaliknya yaitu dengan menerapkan bangunan paham pluralitas yang sempit, yang memaknai bahwa semua agama adalah sama. Kesadaran tidak bersikap taken for granted perlu dimaknai bukan pada tataran konsep semata. Joas Adiprasetya menegaskan bahwa, sikap jujur, ketegasan diri dalam keutuhan iman dan penghargaan terhadap keutuhan diri orang lain sebagai orang yang beriman adalah bentuk praktis dari kesadaran untuk tidak bersikap taken for granted.

Konsep ini penulis pahami sebagai bentuk mencari solusi yang nyata menyentuh dinamika kehidupan diluar opsi atau rangkaian pikiran tentang salah dan benar, atau tentang Kristus yang bagi sebagian orang (teolog) dalam rancang bangun "bingkai" eksklusif, inklusif atau pluralis, yang mengubur harapan dan rintihan penderitaan kaum termajinalkan. Mereka yang hidup dalam kemiskinan dan penderitaan tidak mengharapkan dan membutuhkan "suguhan" Kristus dalam tataran doktrin semata, melainkan Kristus yang berjalan di Galilea menyapa, menyentuh dengan kasih, merawat, memulihkan dan memberikan harapan akan penyelesaian pergumulan kehidupan. Yesus yang menjawab kemanusian dengan keutuhan diri-Nya tanpa kedok dan tanpa takut mendobrak perilaku yang berlawanan dengan ketulusan kasih yang menjadi pilar utama pemberitaan-Nya tentang keutuhan Kerajaan Allah di dalam hidup-Nya. "Seluruh hidup Yesus merupakan ungkapan kasih tidak bersyarat. Dia menyapa setiap orang yang dijumpai-Nya, tidak peduli apakah mereka pemimpin atau pengemis, orang suci atau juga orang berdosa, setiap individu pantas dikasihi”. ${ }^{39}$ Dalam hal inilah kesadaran untuk tidak bersikap taken for granted penting dibahasakan. Albert Nolan membahasakannya sebagai keseluruhan tanpa sambungan. ${ }^{40}$ Nolan memaknai bahwa kesatuan dengan Allah,

${ }^{37}$ Keberadaan yang menjelaskan sikap masa bodoh, cuek atau sebuah awasan untuk serius menghadapi sesuatu yang telah menjadi bagian dari kehidupan ini, bagi terciptanya harmonisasi kehidupan, (jika hal itu yang dimaksudkan oleh Joas Adiprasetya) sehubungan konteks multikultur yang mengakar dalam kekinian bangsa Indonesia.

${ }^{38}$ Joas Adiprasetya, Mencari Dasar Bersama, Etik Global dalam Kajian Postmodernisme dan Pluralisme Agama (Jakarta: BPK Gunung Mulia, 2002), 47.

${ }^{39}$ Nolan, 223.

${ }^{40}$ Ibid., 259. 
dengan diri sendiri, dengan sesama, dan dengan alam semesta membentuk sebuah keseluruhan tanpa sambungan. Setiap usaha dalam kesatuan dengan Allah yang terpisah dari sesama dan dari alam adalah sebuah fantasi. ${ }^{41}$ Nolan menggambarkannya dengan merujuk pada analisis final Yohanes (Yohanes 17:21-23, yang menegaskan bahwa Yesus adalah pewahyuan ketunggalan: Ketunggalan-Nya dengan Allah, ketunggalan Allah dengan diri-Nya dan dengan kita, ketunggalan kita satu sama lain, serta ketunggalan kita dengan Yesus dan dengan Allah. Paulus membahasakannya dalam dimensi kosmiknya, "oleh Dialah Ia memperdamaikan segala sesuatu dengan diri-Nya, baik yang ada di bumi maupun yang ada di surga. Dalam pembahasan lain Paulus menegaskan, "sehingga Allah menjadi semua di dalam semua" (1 Kor. 1:20; 15:28). ${ }^{42}$ Dalam hal ini Nolan memahami bahwa "kesadaran akan ketunggalan kita dan solidaritas secara alamiah dan spontan membawa kita pada semangat berbagi. Setiap gagasan bahwa kita dapat mengasihi satu sama lain tanpa saling berbagi merupakan sebuah ilusi romantis." ${ }^{43}$

Jika Joas Adiprasetya menyarankan agar tidak bersikap taken for granted dalam membangun kesadaran positif terhadap pluralitas atau kemajemukan yang merealitas menjadi fakta kehidupan, maka bagi penulis penting membandingkannya dengan konsep yang dibahasakan Albert Nolan sebagai "kebaikan bersama." ${ }^{44}$ Konsep Nolan tersebut mengarah pada bagunan kelimpahan kasih di dalam dan melalui hidup kita, yang berpusat pada bangunan spiritualitas Yesus yang menjangkau semuanya. Dijelaskan bahwa:

Setiap usaha untuk menghidupi spiritualitas Yesus akan ketunggalan di dalam sebuah keterpisahan, tidak sekadar memberikan pemberianpemberian kepada kaum miskin. Ketunggalan berarti tidak hanya bahwa saya mengidentikkan diri saya dengan yang lain, tetapi bahwa mereka mengidentikkan diri mereka dengan saya juga. Kita saling membutuhkan. Tidak ada jenis spiritualitas yang sempurna yang dapat saya peroleh tanpa bantuan orang lain. Jika sungguh tidak ada orang yang membantu saya,

${ }^{41}$ Ibid., 259.

${ }^{42}$ Ibid., 260.

${ }^{43}$ Nolan, 245.

${ }^{44}$ Nolan, 245. Merujuk pada konsep Albert Nolan tentang "kebaikan bersama" pada prinsipnya dijelaskan Nolan sebagai luapan dari pertumbuhan pengalaman kehidupan dalam kebersamaan dan ketidakterpisahan, dan mengarahkan semua daya upaya pada apa yang disebut sebagai "kebaikan bersama". Konsep ini disejajarkan Nolan pada filosofi, "apa yang terbaik bagi setiap orang adalah terbaik juga bagiku". Nolan menegaskan bahwa: Tidak ada konflik yang mungkin antara kebaikan kita dengan kebaikan bersama. Berbagi muncul secara alamiah di sini. Tidak akan ada kebutuhan untuk memaksa orang untuk berbagi. Ke mana Roh Yesus akan membimbing kita, adalah kerinduan untuk berbagi karena kebaikanmu adalah kebaikanku, dan kita semua tidak menginginkan apa-apa, kecuali kebaikan bersama. 
tidak ada seorang pun untuk berbagi, maka perkembangan saya akan berhenti. Inilah sebabnya mengapa Yesus tidak membatasi diri-Nya pada pertobatan personal dan pencapaian-pencapaian spiritual individualistik. Dia mengumpulkan orang-orang bersama-sama dalam komunitas seperti keluarga sebagai benih-benih Kerajaan yang sedang tumbuh. Dalam komunitas-komunitas semacam itulah para pengikut-Nya menemukan ketunggalan dan solidaritas mereka satu sama lain. Mereka saling menyembuhkan dengan belajar satu sama lain, mengasihi satu sama lain, dan berbagi satu dengan yang lain. Dari dasar semacam itulah kita akan sampai pada semua saudara-saudari sesama manusia dalam solidaritas dan

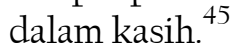

Selanjutnya, ada beberapa hal yang dapat dicontoh dari Yesus, yakni dalam perjalanan pelayananNya yang dapat dimaknai sebagai role model hidup berbelaskasihan dengan membangun "kebaikan bersama" tersebut. Yesus membangun dasar pijakan yang benar sehubungan dengan pelayanan-Nya yang memulihkan dan menghidupkan.

Mengerjakan kehidupan yang berbelaskasihan (Lukas 6:27-35; 7:1117; 10:25-37), pada prinsipnya adalah membangun "kebaikan bersama" dalam tataran lebih tinggi, dalam bahasa Inggrisnya dipakai istilah "better, more than." Apa yang orang percaya lakukan baik itu menyangkut sikap dan tingkah laku keimanan mereka harus bernilai lebih dari apa yang biasanya. ${ }^{46}$ John Wijngaards "berperilaku lebih jauh daripada quid pro quo, lebih jauh daripada perihidup bertimbal balik. Hal ini menyangkut mengampuni daripada membalas dendam, memberi lebih banyak dari yang diterima. ${ }^{47}$ Yesus senantiasa mengerjakan hal-hal yang menakjubkan. Kata Yunani untuk kata "menakjubkan" adalah exeplêssonto (verb indicative imperfect passive 3rd person plural) dari ekplêssô yang artinya be amazed, overwhelmed, ${ }^{48}$ menyatakan keadaan yang telah ditunjukkan, atau menunjuk kepada suatu perbuatan yang telah dikerjakan yang mendatangkan decak kagum (amazed). Frasa Yunani ekplêssô tersebut,

${ }^{45}$ Nolan, 247.

${ }^{46}$ Roma 12:2, "Janganlah kamu menjadi serupa dengan dunia ini, tetapi berubahlah oleh pembaharuan budimu, sehingga kamu dapat membedakan manakah kehendak Allah: apa yang baik, yang berkenan kepada Allah dan yang sempurna." Matius 5:46, "Apabila kamu mengasihi orang yang mengasihi kamu, apakah upahmu? Bukankah pemungut cukai juga berbuat demikian?" Matius 5:47, "Dan apabila kamu hanya memberi salam kepada saudara-saudaramu saja, apakah lebihnya dari pada perbuatan orang lain? Bukankah orang yang tidak mengenal Allah pun berbuat demikian?"

${ }^{47}$ Keadaannya bisa disejajarkan dengan apa yang Yesus katakan, yakni “Jika hidup keagamaanmu tidak lebih benar daripada hidup keagamaan alhi-ahli taurat dan orangorang Farisi, sesungguhnya kamu tidak akan masuk ke dalam Kerajaan Allah" (Mat. 5:10). Bandingkan dengan apa yang dicatatkan Lukas tentang kasih penuh-menyeluruh yang dibahasakan John Wijngaards lebih dari sekadar quid pro quo (bdg. Luk. 6:27-37).

${ }^{48}$ Bible Works, s.v. "ekplêssomai." 
dicatatkan D. H. Field sebagai berikut:

Ekplêssô occurs 13 times in the NT, but only once outside the Gospels. It is always found in the passive (ekplesssomai, be amazed). Usually it expresses the astonished reaction of uncommitted onlookers to Jesus' teaching (e.g. Mk. 1:22 par.; 6:2 par.) and -just once- to a demonstration of his healing power (Lk. 9:43). Only Luke names individuals as the subject of ekplessomai: Mary and Joseph are amazed to find the boy Jesus sitting among the temple teachers (Lk. 2: 48), and the proconsul Sergius Paulus is "astonished at the teaching of the Lord" (Acts 13: 12). ${ }^{49}$

Lukas mencatat bahwa semua orang yang mendengar pengajaranNya dan peristiwa-peristiwa yang menyatakan kebesaran kuasa-Nya, takjub (ekplêssô yang artinya [be amazed, overwhelmed ]). ${ }^{50}$ Konsep ini sangat sempurna dibangun oleh Yesus sehubungan dengan menerapkan suatu ukuran yang terbaik, yakni merujuk pada kisah/perumpamaan (the golden compassion story) Yesus perumpamaan tentang orang Samaria yang murah hati (Lukas 10:25-37).

Untuk memahami perumpamaan ini dalam hubungannya dengan membangun identitas Kristen dalam realitas berbelaskasihan, maka beberapa pola kajian dari perumpamaan ini dapat dijelaskan sebagai berikut.

Menghadapi pergumulan hidup Kristen di tengah masyarakat dan tantangan sosial yang semakin kompleks, para orang percaya harus mengerjakan standar tunggal, bukan standar ganda. Apa yang orang Kristen yakini itulah yang dihidupi. Setiap karya dari pribadi Kristen adalah keutuhan diri Kristen yang menggambarkaan pekerjaan tersebut. Di sinilah nilai otoritas membentuk identitas diri yang nampak pada integritas hidup, dengan penuh tanggung jawab menentukan sikap/pilihan hidup. ${ }^{51}$

Orang Samaria memilih untuk memberikan pertolongan tuntas, yaitu pertolongan yang lebih tinggi, bukan (quid pro quo) tetapi kasih yang dalam pandangan orang dunia (Imam dan Lewi) tidak mampu dikerjakan/mustahil mengerjakannya, tetapi orang Samaria mampu mengerjakannya dengan tuntas. Hal inilah yang dituntut dari kehidupan orang percaya, dalam keberadaan apapun dan dimanapun, bukan menjadi orang Samaria tetapi tampil sebagai orang Samaria yang murah

${ }^{49}$ D. H. Field, "Ecstasy/Egypt" dalam The New International Dictionary Of New Testament Theology, volume I: A-F, eds. Colin Brown, et.al.,530.

${ }^{50}$ Bible Works 7, s.v. "ekplêssô."

${ }^{51}$ Penulis memahami bahwa tidak mungkin kekristenan diperhadapkan pada standar ganda, jika demikian maka kekristenan telah kehilangan identitasnya dan tidak akan mampu menjawab tuntutan integritas yang membentuk sikap hidup tersebut. Kekristenan akan kehilangan sentuhannya (the lost of Christianity movement). 
hati. Dalam setiap panggilan hidup Kristen yang berhadapan dengan keberagaman konteks, realitas sosial yang kompleks, beragam kebutuhan menanti kehadiran orang Kristen yang tampil sebagai orang Samaria yang murah hati yang berdampak memulihkan, bukan menciptakan kehancuran.

Membangun identitas Kristen dalam realitas berbelaskasihan adalah menampilkan kekayaan iman Kristen bukan dengan menjual keyakinan tetapi dengan membagi keyakinan berdasarkan kekayaan hati yang penuh kemurahan dan tergerak oleh belas kasihan. Orang tidak melihat apa yang kita pikirkan, tetapi apa yang kita bawa untuk kita lakukan dan memberi kehidupan kepada sesama.

Kasih yang membawa kepada keselamatan bukanlah bentuk kasih pragmatis, tetapi kasih reflektif-realistis. Kasih yang menjawab dan hadir sebagai pemberi jawab. Di manapun kekristenan, kehadirannya tidak hanya sekadar berbicara kasih, karena semua orang pun bisa, tidak perlu ia mengenal dan hidup di dalam Kristus, kalau hanya untuk berbicara kasih. Setiap orang yang hidup di dalam Kristus, telah mengalami kasih sejati yang Kristus berikan, nyatakan, maka selayaknya pun berlaku hal yang sama (Luk. 6:27-38). Maka kasih di sini adalah perbuatan, perbuatan yang mencapai nilai tertinggi.

Jika merujuk kepada orang Samaria yang murah hati. Kasihnya adalah wujud keluapan kepenuhan pada puncak yang tertinggi. Kekuatan otoritaslah yang membentuk identitas kasih yang sejati. Yesus telah mengalaminya, "Ya Bapa-Ku, jikalau Engkau mau, ambillah cawan ini dari pada-Ku; tetapi bukanlah kehendak-Ku, melainkan kehendakMulah yang terjadi” (Luk. 22:42).

Dengan demikian dapat disimpulkan bahwa realitas hidup berbelaskasihan adalah mengerjakan keutuhan nilai kehidupan yang menyentuh keutuhan kehidupan diri dan orang lain. Ada dua hal yang dibahas pada bagian ini yang menegaskan tentang pentingnya berperilaku berbelarasa atau berbelaskasihan tersebut yaitu: Pertama, berbelaskasihan adalah menghadirkan kesiapan bersama, yakni semua pihak di dalam keutuhan bersikap proaktif membangun kebaikan bersama sebagai hubungan tiada terputus, sehingga kenyataan yang ada yang cenderung memperlihatkan praktik tidak menghargai keberagaman, dengan sendirinya sirna. Kedua, menegaskan kebaikan bersama tersebut dengan mengambil pelajaran positif dari perumpamaan orang Samaria yang baik hati. Karena itu, makna mendidik untuk berbelaskasihan adalah mendidik dalam perhatian, pembangunan dan pembentukan manusia sebagai sesama kita.

Kehidupan Kristen adalah realitas dari spiritualitas turun ke bawah, bukan hanya melihat ke atas. Konsep yang penulis angkat tersebut yakni spiritualitas "melihat ke bawah" bukan "melihat ke atas," adalah 
gambaran spiritualitas Kristen yang memedulikan sesama, yang hidup bersama semangat keprihatinan dan kepekaan terhadap penderitaan dan harapan akan pemulihan sesama. Spiritualitas ini pada hakikatnya menyentuh kesiapan untuk berkorban. Namun demikian, bukan berarti menghilangkan pentingnya "spiritualitas melihat ke atas." Yesus telah mengerjakan model spiritualitas melihat ke bawah, yang didasarkan pada otoritas yakni spiritualitas dari atas. Dalam Lukas 22:42, "Ya Bapa$\mathrm{Ku}$, jikalau Engkau mau, ambillah cawan ini dari pada-Ku; tetapi bukanlah kehendak-Ku, melainkan kehendak-Mulah yang terjadi". Spiritualitas "melihat ke bawah" Yesus bersumber dari spiritualitas melihat ke atas, yakni kekuatan untuk taat mengerjakan spiritualitas melihat ke bawah yaitu pengorbanan penebusan-Nya. Spiritualitas melihat ke bawah dan spiritualitas melihat ke atas telah dikerjakan tuntas dalam spiritualitas paskah Yesus. ${ }^{52}$

Gerald W. Schlabach, menulis beberapa pesan teks tersebut dengan menghubungkannya dalam tugas belarasa orang percaya, yaitu:

The lawyer finally had to admit that the question of who is the neighbor had nothing to do with which needy ones deserved. One of those he surely thought undeserving provided the model of neighborliness. A despised Samaritan was "the one who had mercy." What is this model of love and mercy? Who is this neighbor? Are we neighborly, as this one was? It cost the Samaritan something to love. What costs might we need to bear? What privilege might we need to give up? What "inconvenience" might we need to take on? The Samaritan loved without any prospect that the roadside victim would return that love or even express gratitude. What determines our willingness to become the neighbor? Do we love, expecting something in return? If so, have we really loved? The Samaritan's commitment to the other was open-ended and ongoing. How far are we willing to go in becoming the neighbor? Have we already placed limits on how far we will go in relation to those who are poor? What might those limits be? ? $^{53}$

\footnotetext{
52 Dengan demikian konsep ini tidak ada kaitannya dengan bangunan "kristologi dari atas" dan "kristologi dari bawah." Gerakan "kristologi dari bawah" yang menanggapi "gerakan "kristologi dari atas" dari Kristologi tradisonal yang menekankan bahwa Yesus Kristus "sehakikat dengan Bapa" (jadi: Allah). Gerakan "kristologi dari bawah" yang dimunculkan oleh gelombang rasionalisme dan emperisme selama abad XVIII dan XIX, menekankan bahwa "Yesus sehakikat dengan kita", bahkan menekankan pada "manusia" Yesus Kristus. Gerakan ini pertama kali dibuka oleh seorang orientalis Jerman H.S. Reimarus ( \pm tahun 1766 ) yang menggali dan berupaya menemukan Yesus sejarah, yang terbebas dari bungkusan mitos dan dan dogma yang mengubah Yesus menjadi Anak Allah dan Juruselamat. Lihat C. Groenen, Sejarah Dogma Kristologi: Perkembangan Pemikiran Tentang Yesus Kristus pada Umat Kristen (Yogyakarta: Kanisius, 1988), 215.

${ }^{53}$ Schlabach, 117.
} 


\section{Kesimpulan}

Identitas kehidupan Kristen didirikan pada dataran berbelaskasihan, maka sikap belas kasihan dalam ketulusan dan kerelaan adalah tiang kokohnya. Terciptanya kehidupan berbagi yang semakin menyentuh kedalaman kehidupan spiritualitas yang memulihkan, menghidupkan dan menyelamatkan adalah identitas hidup Kristen. Kekristenan menghadapi berbagai tantangan tidak hanya bergerak pada tataran konsep, tetapi memproklamasikan sikap yang membangun perubahan hidup. Hal itu menegaskan bahwa kematangan konsep tentang kehidupan dengan sendirinya bermakna memberdayakan kehidupan senada dengan kematangan konsep tersebut. Belas kasihan orang Samaria yang tampak adalah akibat kepenuhan belas kasihan di dalam hatinya, atau melimpah ruah di dalam hatinya. Sangat paradoks apabila menegaskan diri rohani, tetapi sikap hidup jauh dari tabiat atau karakter hidup rohani tersebut.

Sehubungan dengan upaya membangun identitas Kristen dalam realitas berbelaskasihan, teladan Yesus yang menyatakan kasih kepada setiap orang bahkan kepada bangsa-bangsa lain haruslah didasarkan pada kepekaan kasih yang lebih tinggi. Kasih manusia semuanya berhenti pada keegoisan dan keuntungan. Melalui perumpamaan tentang orang Samaria yang murah hati, realitas hidup Kristen harus membangun kasih yang utuh dan lebih tinggi derajatnya yaitu kasih yang memulihkan dan menghidupkan orang lain, dan kasih itu adalah realitas kerajaan Allah.

Dengan kesiapan belajar dari perumpamaan orang Samaria yang murah hati akan menjadikan identitas kekristenan dalam keutuhannya mampu menyentuh berbagai kebutuhan dan pencapaian panggilan hidup yang memulihkan kehidupan setiap orang.

\section{Kepustakaan}

Adiprasetya, Joas. Mencari Dasar Bersama, Etik Global dalam Kajian

Postmodernisme dan Pluralisme Agama. Jakarta: BPK Gunung Mulia, 2002.

Bible Works. CD-ROM, Version 7.0.

Boland, B. J. dan P.S. Naipospos, Tafsiran Alkitab Injil Lukas. Jakarta: BPK Gunung Mulia, 1996.

Brown, Colin. The New International Dictionary of New Testament Theology, Vol. 3: Pri-Z, edited by Colin Brown, et.al. Grand Rapids, Michigan: Regency Reference Library, 1975. 
Brownlee, Malcolm. Tugas Manusia dalam Dunia Milik Tuhan, Dasar Theologis Bagi Pekerjaan Orang Kristen dalam Masyarakat. Jakarta: BPK Gunung Mulia, 1997.

Ellis, E. Earle. The Gospel of Luke, The New Century Bible Commentary. Grand Rapids: Wm. B. Eerdmans Publishing Company, 1987.

Fletcher, Verne H. Lihatlah Sang Manusia, Suatu Pendekatan pada Etika Kristen Dasar. Jakarta: BPK Gunung Mulia, 2007.

Groenen, C. Sejarah Dogma Kristologi: Perkembangan Pemikiran Tentang Yesus Kristus pada Umat Kristen. Yogyakarta: Kanisius, 1988.

Groome, Thomas A. Christian Religious Education; Pendidikan Agama Kristen, Berbagi Cerita dan Visi Kita. Jakarta: BPK Gunung Mulia, 2010.

Hendriksen, William. New Testament Commentary, Exposition of the Gospel According to Luke. Grand Rapid, Michigan: Baker Book House, 1987.

Hunter, A. M. Christ and the Kingdom: What Scripture Says about Living in the Kingdom of God. Michigan: Servant Books, 1980.

Hunter, Archibald M. The Work and Words of Jesus. Philadelphia: The Westminster Press, 1973.

Johnson, Luke Timothy. "The Lukan Kingship Parable (Luk. 19:11-27)" dalam Luke the Composition of Luke's Gospel, Selected Studies from Novum Testamentum, edited by Davide Orton. Leiden, Boston: Brill, 1999.

Kasper, Walter. Jesus the Christ. New York: T\&T Clark International, 2011.

Küng, Hans. "Kekhasan Etika Kristen" dalam Fletcher, Verne H. Lihatlah Sang Manusia, Suatu Pendekatan pada Etika Kristen Dasar. Jakarta: BPK Gunung Mulia, 2007.

Leks, Stefan. Tafsir Injil Lukas. Yogyakarta: Kanisius, 2003.

Marshall, I. Howard. Luke: Historian and Theologian, CEP. Grand Rapid, Michigan: Zondervan Publishing House, 1979.

Merkel, Helmut. "The opposition between Jesus and Judaism" in Jesus and The Politics of His Day, edited by Ernst Bammel, C. F. D. Moule. Cambridge, London: Cambridge University Press, 1984.

Nolan, Albert. Yesus Sebelum Agama Kristen, Warta Gembira yang Memerdekakan. Yogyakarta: Kanisius, 1991.Adiprasetya, Joas Mencari Dasar Bersama, Etik Global dalam Kajian Postmodernisme dan Pluralisme Agama. Jakarta: BPK Gunung Mulia, 2002.

Robinson, James M. The Gospel Jesus, A Historical Search for the Original Good News. New York: Hmper Collms Publishers, 2005.

Schlabach, Gerald W. And Who is My Neighbor? Poverty, Privilege, and the Gospel of Christ. Waterloo: Herald Press, 1990. 
Scofield, C. I. The Scofield Study Bible, New King James Version. Oxford, New York: Oxford University Press, 2002.

Utley, Bob. Luke the Historian: The Gospel of Luke, Study Guide Commentary Series New Testament, vol. 3A. Marshall, Texas: Bible Lessons International, 2011.

Widyatmadja, Josef P. Yesus dan Wong Cilik. Jakarta: BPK Gunung Mulia, 2011.

Wijngaards, John. Yesus Sang Pembebas. Yogyakarta: Kanisius, 1994.

Wolterstorff, Nicholas P. Mendidik untuk Kehidupan, Refleksi Mengenai Pengajaran dan Pembelajaran Kristen, diterjemahkan oleh Lana Asali. Surabaya: Momentum, 2004.

Yewangoe, A. A. "Kata Pengantar" dalam Josef P. Widyatmadja, Yesus dan Wong Cilik. Jakarta: BPK Gunung Mulia, 2011. 